\title{
Economic Returns from Treating Sand Shinnery Oak with Tebuthiuron in West Texas
}

\author{
D.E. ETHRIDGE, R.D. PETTIT, T.J. NEAL, AND V.E. JONES
}

\section{Abstract}

Net returns from control of sand shinnery oak (Quercus havardii) with tebuthiuron [N-(5-1,1-dimethylethyl 1,3,4,-thiadiazol-2yl-N, N'-dimethylurea] were evaluated for Southern High Plains ranges. A forage yield function was estimated with regression using 5 years of herbage yield data from the region. The present value of production was determined for 3 calf prices, 3 discount rates, and 4 tebuthiuron treatment rates. Discounted net returns were generally positive with high and moderate calf prices and low and moderate discount rates. The optimum tebuthiuron treatment rate varies with calf prices, discount rate, and treatment cost.

Key Words: sand shinnery oak, brush control, economic evaluation

Sand shinnery oak (Quercus havardii), an undesirable shrub for livestock producers, is found on rangeland in west Texas, eastern New Mexico, and southwestern Oklahoma. It grows on deep sandy soils or on sand underlain by clay or caliche. The deciduous oak is rarely over $1 \mathrm{~m}$ tall and it grows in a precipitation zone from 30 $\mathrm{cm} / \mathrm{yr}$ in southeastern New Mexico to $66 \mathrm{~cm} / \mathrm{yr}$ in western Oklahoma (Jones 1982). Forage production may be reduced more than 60\% below that of noninfested range (Robinson and Fisher 1968) and may cause livestock poisoning in the spring following dry winters when grasses are not green (Pettit 1979).

Conventional control for oak has been silvex [2-(2,4,5-trichlorophenoxy) propionic acid] and 2,4,5-T [(2,4,b-trichlorophenoxy acetic acid], but only top growth is usually killed and increased grass yields may last only 2-3 years (Scifres 1972a, 1972b). Control of sand shinnery oak with tebuthiuron is long-term. Results in west Texas indicate oak reductions of 79-99\% (Pettit 1979; Jones 1982; Jones and Pettit 1980; Herndon and Pettit 1978) with no reinfestation after 13 years. Thus, the technical feasibility of tebuthiuron for oak control has been shown. The objective of this study was to determine potential economic returns from using tebuthiuron on oak ranges in west Texas.

\section{Methods and Procedures}

The approach for the analysis was (a) estimating forage response after using tebuthiuron, (b) valuing the added grass through livestock production, and (c) discounting net income over time. The model used was similar to that of Ethridge, Dahl and Sosebee (1984). The forage response relationship was estimated using ordinary least squares multiple regression. Seventy-two forage yield observations in different locations over 5 years were taken from the most typical oak site in Yoakum County, Texas. The response is representative of the west Texas-eastern New Mexico High Plains region. Four years of data were from Jones (1982) and the fifth year's data were from Jones and Pettit (1984). All data were taken on Brownfield fine sand, an Arenic Aridic Paleustalf. The experimental design was completely randomized with 3 replications of the 2.5 -ha plots. Thirty $0.5-\mathrm{m}^{2}$ quadrats were clipped in each treatment. Independent variables to explain forage yield included tebuthiuron treatment rates $(0.2,0.4,0.6,0.8,1.0 \mathrm{~kg} / \mathrm{ha})$, number

\footnotetext{
Authors are professor, Agricultural Economics Department; associate professor, Range and Wildlife Manegement Department; and former research assistants, Agricultural Economics and Range Wildlife Management Departments, Texas Tech University, Lubbock 79409

The authors wish to thank Bob Davis, A.L. Stoecker, H.A. Wright, R.H. Hart, and two anonymous reviewers for their assistance in the preparation of this paper.

This article is Texas Tech University, College of Agricultural Sciences Publication No. T-1-219.

Manuscript accepted 9 March 1987.
}

of years since treatment, rainfall in different periods of the year, and sand depth in the soil profile.

Total forage (grass plus usable forbs) production (TFP) from tebuthiuron treatment was converted to added forage by subtracting the $200 \mathrm{~kg} /$ ha produced with no treatment; $M F P=T F P-200$, where MFP is additional forage production from tebuthiuron in $\mathrm{kg} / \mathrm{ha}$. To determine value of added forage, a cow-calf operation with a $90 \%$ calving rate, $1 \%$ death loss, $14 \%$ heifer replacement, and marketing $181 \mathrm{~kg}$ calves was used. An animal producing unit (APU) was a $454-\mathrm{kg}$ cow with calf, $5 \%$ of a $726-\mathrm{kg}$ bull, and $14 \%$ of a $295-\mathrm{kg}$ replacement heifer. An estimated $9,526 \mathrm{~kg}$ of herbage is required annually to support an APU with continuous grazing, which is typical in the area (Ethridge et al. 1984). This reflects proper use, forage disappearance, trampling, and other losses. Given the calving rate, death loss, and heifer replacement pattern, $138 \mathrm{~kg}$ of calf was marketed from each APU. This gives a conversion of $1 \mathrm{~kg}$ of herbage $=.0145 \mathrm{~kg}$ of marketed calf. Thus, MLP $=$ .0145 MFP, where MLP is additional livestock production in kilograms of marketable calves.

Treatment returns were determined using 3 different calf prices and adjusting for (a) added production costs with a higher stocking rate and (b) income from the sale of cull cows. The added production costs consist of the additional feed, medical, marketing and other variable costs which are increased when APUs are added to the ranch. Cull cow income was adjusted because cow prices fluctuate as calf prices fluctuate; $\mathrm{PC}=.1165+.4674 \mathrm{~PB}$ (Ethridge et al. 1985 ), where $P C$ is the price of cull cows in $\$ / \mathrm{kg}$ and $P B$ is the price of $181 \mathrm{~kg}$ calves in $\$ / \mathrm{kg}$. Revenue from sale of cull cows was deducted from the variable cost of producing calves. Thus, cull cow value was: $\mathrm{CCV}=\mathrm{PC}(408)(.14)(.99)$ where $\mathrm{CCV}$ is cull cow revenue per APU, $408 \mathrm{~kg}$ is the weight of cull cows, .14 is heifer replacement proportion, and .99 is the survival rate (1 minus death loss proportion). The added production cost (additional supplemental feed, labor, veterinary costs, interest cost on the cattle, etc.) was estimated to be \$132.44/APU (Tex. Agr. Extension Serv. 1984). The added cost per $\mathrm{kg}$ of calves sold (VCC) was: VCC $=$ $(\$ 132.44-44-\mathrm{CCV}) /(181)(.76)=.912-.192 \mathrm{~PB}$, where 181 is the weight of calves in kilograms and .76 is the proportion of calves sold per APU (calving rate minus heifer replacement rate). The net price of beef sold was NPB $=$ PB - VCC $=1.192$ PB -.912 . Further, the additional revenue from the tebuthiuron treatment, VMP, was VMP = (MLP)(NPB), where VMP is in \$/ ha and is a function of time (years) if TFP changes over time.

With the forage response function, calf production and marketing conditions, and given rainfall, treatment rate, and calf prices, added revenue was estimated for each future year in which the treatment was effective. This added revenue was discounted and cost of tebuthiuron application was subtracted to get a net present value of oak control; PVMP $=\sum^{R}\left[V^{\prime} P_{t} /(1+r)^{t}\right]$, where PVMP is the present value of the stream of added revenue over $n$, the life of treatment in years, $\mathrm{VMP}_{t}$ is the added revenue in year $\mathrm{t}$, and $\mathrm{r}$ is the discount rate (the cost of the investment capital in the treatment). Tebuthiuron cost is $\$ 66.14 / \mathrm{kg}$ of active ingredient and cost of application is $\$ 2.47 /$ ha plus $\$ 6.66 /$ ha for each $\mathrm{kg}$ of active ingredient. Thus, CT $=72.8 \mathrm{TR}+2.47$, where CT is treatment cost in S/ha and TR is tebuthiuron treatment rate in $\mathrm{kg} / \mathrm{ha}$, and NPV = PVMP - CT, where NPV is the net present value of the net returns from the treatment over its useful life. Tebuthiuron appears to permanently kill oak in the area, but the life of the treatment in this 
Table 1. Net present value from treating sand shlmnery oak with tebuthiuron in weat Texas with different cattle prices and diccount rates.

\begin{tabular}{|c|c|c|c|c|c|c|c|c|c|c|c|c|}
\hline \multirow{3}{*}{$\begin{array}{l}\text { Tebuthiuron } \\
\text { treatment } \\
\text { rate }\end{array}$} & \multicolumn{12}{|c|}{ Calf prices, $\$ / \mathbf{k g}$} \\
\hline & \multicolumn{4}{|c|}{$\begin{array}{c}1.43 \\
\text { discount rate }\end{array}$} & \multicolumn{4}{|c|}{$\begin{array}{c}1.65 \\
\text { discount rate }\end{array}$} & \multicolumn{4}{|c|}{$\begin{array}{c}1.87 \\
\text { discount rate }\end{array}$} \\
\hline & $7.5 \%$ & $10 \%$ & 12.5 & $15 \%$ & $7.5 \%$ & $10 \%$ & $12.5 \%$ & $15 \%$ & $7.5 \%$ & $10 \%$ & $12.5 \%$ & $15 \%$ \\
\hline \multirow{5}{*}{$\begin{array}{l}-\mathbf{k g} / \mathrm{ha}- \\
0.28 \\
0.56 \\
0.84 \\
1.12\end{array}$} & & & & & & -4 & & & & & & \\
\hline & 12.22 & 6.78 & 2.47 & -0.99 & 23.76 & 16.53 & 10.80 & 6.21 & 35.30 & 26.69 & 19.14 & 13.72 \\
\hline & 13.80 & 4.91 & -2.12 & -7.77 & 32.58 & 20.76 & 11.41 & 3.91 & 51.35 & 37.27 & 24.94 & 16.08 \\
\hline & 1.57 & -8.67 & -16.77 & -23.25 & 23.02 & 9.41 & -1.35 & -9.97 & 44.47 & 28.24 & 14.07 & 3.87 \\
\hline & -24.51 & -33.99 & -41.48 & -47.47 & -4.93 & -17.53 & -27.49 & -35.45 & 14.65 & -0.41 & -13.50 & -22.93 \\
\hline
\end{tabular}

analysis was 15 years. Net returns beyond 15 years are increasingly uncertain and have little effect on net present value.

\section{Results and Interpretation}

Several mathematical forms were developed and evaluated for the annual herbage yield response relationship. The relationship selected was:

$$
\text { TFP }=-951+1786(T R)-975(T R)^{2}-504(T R / t)+63(R)
$$$$
\begin{array}{lllll}
(.0001) & (.0001) & (.0094) & (.0142) & (.0001)
\end{array}
$$

where TFP = total annual forage yield with application of tebuthiuron (kg/ha),

$T R=$ rate of tebuthiuron application $(\mathrm{kg} / \mathrm{ha})$,

$\mathbf{R}=$ May through August rainfall $(\mathrm{cm})$, and

$t=$ no. years after application of tebuthiuron.

Numbers in parentheses below estimated parameters are significance levels for the parameters. The model explained $61 \%$ of the total variation in herbage yields $\left(R^{2}=.61\right)$ with the 5 years of data, Parameters for sand depth and rainfall during other periods of the year were not significant.

Net present values of added herbage from 4 application rates of tebuthiuron were estimated at 4 discount rates and 3 calf prices (Table 1). May-August rainfall was held constant as its mean value, $18.2 \mathrm{~cm}$, the treated range was deferred from grazing the year following treatment with no income derived that year, and the ranch incurred the full cost of treatment. If the government subsidized the treatment cost by, e.g., \$5/ha, the net returns in Table I would increase by that amount.

Table 1 gives discounted net returns to treatment; positive values indicate a profit and negative values a loss. Discounted net returns are sensitive to treatment rate, cattle prices, and discount rate. The 0.84 and $1.12 \mathrm{~kg} /$ ha treatment rates were less profitable than lower rates in the area. The more profitable choice of the 0.28 or 0.56 $\mathrm{kg} /$ ha rates depend on expected cattle prices and the discount rate. In this study, no treatment with low cattle prices $(\$ 1.43 / \mathrm{kg})$ and a $15 \%$ discount rate gave positive net returns. With moderate $(\$ 1.65 / \mathrm{kg})$ and high $(\$ 1.87 / \mathrm{kg})$ calf prices and a $10 \%$ discount rate, $0.56 \mathrm{~kg} / \mathrm{ha}$ of tebuthiuron provided the greatest net returns $(.28$ $\mathrm{kg}$ / ha greatest returns with moderate prices and a $15 \%$ discount rate). While the approved application rate in the area is $0.56 \mathrm{~kg} / \mathrm{ha}$ at the time of the study, ranchers can select the rate of tebuthiuron applied.

Tebuthiuron at $0.56 \mathrm{~kg} /$ ha costs $\$ 43 /$ ha on land whose market value may not exceed $\$ 250 /$ ha. This makes the economic feasibility sensitive to chemical cost, especially at low livestock prices and high discount rates. If the cost of tebuthiuron decreased from $\$ 66.14 / \mathrm{kg}$ to $\$ 55.12 / \mathrm{kg}$, the net present values in Table 1 would increase by $\$ 3.08 /$ ha to $\$ 12.34 /$ ha, depending on treatment rate.

The optimum rate for tebuthiuron depends on calf prices, cost of treatment, discount rate, and precipitation after treatment. The optimum is where the change in net present value from a unit change in treatment rate becomes 0 (stop increasing the treatment rate when the income from the incremental addition of tebuthiuron just covers its cost). The first order condition for optimal applica- tion rate occurs where $\partial \mathrm{NPV} / \partial \mathrm{TRR}=0$. For the production, marketing, and cost conditions used here,

$$
\begin{aligned}
\text { DNPV } / \text { TTR }= & (30.86 \mathrm{~PB}-23.61)\left[\sum_{t=1}^{15} 1 /(1+r)^{t}\right] \\
& -(8.71 \mathrm{~PB}-6.66)\left[\sum_{t=1}^{19} 1 / t(1+r)^{t}\right] \\
& -2 \mathrm{TR}(16.85-12.90)\left[\sum_{t=1}^{15} 1 /(1+r)^{t}\right]-72.8
\end{aligned}
$$

By equating to 0 and solving for TR, the optimum TR may be obtained for any combination of $P B$ and $r$. If $r=.10$, the optimum TR for $\$ 1.43, \$ 1.65$, and $\$ 1.87 / \mathrm{kg}$. calf prices is $0.41,0.52$, and 0.58 $\mathrm{kg} / \mathrm{ha}$, respectively. If $r=.15$, optima are $0.27,0.41$, and 0.49 . Most of these rates are slightly below but relatively close to the commercially approved label $0.56 \mathrm{~kg} /$ ha rate in the area. This is consistent with the analysis by Neal (1983), which examined treatment rate but not economic feasibility.

\section{Conclusions}

Returns from treating sand shinnery oak with tebuthiuron in the Southern High Plains of Texas vary with many factors, including treatment rate, livestock prices, discount rates, rainfall, and cost of tebuthiuron. In all cases analyzed, tebuthiuron at $0.56 \mathrm{~kg} / \mathrm{ha}$ or less was more profitable than higher rates. The $0.56 \mathrm{~kg} / \mathrm{ha}$ treatment is a reasonable approximation of the optimum application rate escept when (1) calf prices are low $(\$ 1.43 / \mathrm{kg}$ and less) and discount rates are $10 \%$ and greater and (2) calf prices are moderate $(\$ 1.65 / \mathrm{kg})$ and discount rates are $12.5 \%$ or more. The $0.56 \mathrm{~kg} / \mathrm{ha}$ treatment rate gave positive net returns with discount rates $10 \%$ and less and calf prices $\$ 1.43 / \mathrm{kg}$ and greater. With calf prices $\$ 1.65 / \mathrm{kg}$ or more, treatment with $0.56 \mathrm{~kg} / \mathrm{ha}$ was profitable at a discount rate of $15 \%$.

Several ranchers in the area have been interviewed concerning the use of tebuthiuron to control sand shinnery oak. Most estimated that the treatment has a payback period of 3 to 6 years. On-going research suggests that stocking rates in the area can be doubled or tripled after the oak is killed.

The estimated returns represent general conditions for the region and the environmental conditions specified, but not necessarily for individual ranchers. The analysis applies only to sandy soils; higher tebuthiuron application rates may be required on finer-textured soils for effective kill of the oak. Additionally, economic returns will also have year-to-year variation in growing season rainfall, and differences in cattle enterprise costs will affect the economics of treatment.

\section{Literature Cited}

Ethridge, D.E., B.E. Dahl, and R.E. Sosebee. 1984. Economic evaluation of chemical mesquite control using 2,4,5-T. J. Range Manage. 37:152-156. Ethridge, D.E., R.G. Sudderth, and H.A. Wright. 1985. Economic returns from burning tobosagrass in the Texas Rolling Plains. J. Range Manage. 38:362-365.

Henderson, E.G., and R.D. Pettit. 1978. Mixed shinnery in panhandleherbicide tests. 1978 noxious brush and weed control research highlights. Range and Wildlife Manage., Texas Tech. Univ. 9:37.

Jones, V.E. 1982. Effects of tebuthiuron on a sand shinnery oak community. Ph.D. diss., Texas Tech Univ. 
Jones, V.E., and R.D. Pettit. 1980. Graslan diminishes drought effects. 1980 noxious brush and weed control research highlights, Range and Wildlife Manage., Texas Tech Univ. 11:35.

Jones, V.E., and R.D. Pettit. 1984. Low rates of tebuthiuron control sand shinnery oak. J. Range Manage. 37:488-490.

Neal, T.J. 1983. Optimum treatment rate for tebuthiuron on rangeland infested with sand shinnery oak. Amer. J. Agr. Econ. 65:1198-1201. Pettit, R.D. 1979. Effects of picloram and tebuthiuron pellets on sand shinnery oak communities. J. Range Manage. 32:196-200.
Robinson, E.D., and C.E. Fisher. 1968. Chemical control of sand shinnery oak. Brush research in Texas. Tex. Agr. Exp. Sta. Prog. Rep. 2583, p. 5-8.

Scifres, C.J. 1972a. Herbicide interactions in control of sand shinnery oak. J. Range Manage. 25:386-389.

Scifres, C.J. 1972b. Sand shinnery oak response to silvex sprays of varying characteristics. J. Range Manage. 25:464-466.

Texas Agricultural Extension Service. 1984. Texas crop and livestock enterprise budgets. Texas A\&M Univ. 